Article

\title{
Infrastructure of the Spatial Information in the European Community (INSPIRE) Based on Examples of Italy and Poland
}

\author{
Marek Ogryzek $^{1, *\left(\mathbb{D}, \text { Eufemia Tarantino }^{2}(\mathbb{D}) \text { and Krzysztof Rząsa }\right.}{ }^{1}$ (D) \\ 1 Department of Land Management and GIS, Faculty of Geoengineering, Institute of Spatial Management and \\ Geography, University of Warmia and Mazury in Olsztyn, 10-720 Olsztyn, Poland; \\ krzysztof.rzasa@uwm.edu.pl \\ 2 DICATECh—Department of Civil, Environmental, Land, Building Engineering and Chemistry, \\ Polytechnic University of Bari, 70125 Bari, Italy; eufemia.tarantino@poliba.it \\ * Correspondence: marek.ogryzek@uwm.edu.pl
}

Received: 22 October 2020; Accepted: 11 December 2020; Published: 16 December 2020

\begin{abstract}
Binding and planned community regulations regarding INSPIRE and other documents resulting from work on INSPIRE have forced the member countries to implement new or updated regulations. The purpose of creating the spatial information infrastructure was to unify the exchange of geographical data at the national and international levels, create transparent and favorable conditions for the use of geographical data, facilitate decision-making and develop business activity, and, as a consequence, facilitate the creation of the INSPIRE geoportal by the European Research Center (JRC) of the European Commission, which aims be the central hub of the European spatial information infrastructure. Land management systems use layers from geoportals and are also a data source because their task is to develop sustainable space development. The article presents the rules for implementing EU directives in Poland and Italy at various levels of detail and examines access to data and spatial information infrastructure. A comparative analysis of geoportals was performed in terms of the functionality and availability of free data (types of data) at national and local levels in terms of verification of compliance with the Ubiquitous Public Access Context Information Model (UPA) defined by the International Organization for Standardization (ISO) 19100. National geoportals (Polish Geoportal 2 and the Italian-Geoportale Nazionale) and Municipal Spatial Information Systems from the cities of Olsztyn and Bari were compared.
\end{abstract}

Keywords: INSPIRE; geoportal; webGIS; ISO 19100; sustainability; NASC

\section{Introduction}

The development of geoportals has resulted in easy access to spatial information. Cartographers used to draw maps, analyze them, and use them for orientation, and now they have converted them to digital form. Geoinformation is used in many areas of people's lives [1]. There are a large number of databases in the European Community countries, which are scattered over a number of institutions depending on the area concerned. It is very time-consuming to collect comprehensive spatial information on a given region, and it is almost impossible to compare data between different EU countries because they were not previously harmonised. To change this situation, in 2007, the European Commission adopted the INSPIRE Directive (Directive 2007/2/EC of the European Parliament and of the Council of 14 March 2007) to establish an Infrastructure for Spatial Information in the European Community, whose main objective is to facilitate and accelerate access to data and to increase the possibility of data exchange within EU countries [2]. The development of Spatial Data Infrastructure (SDI) is an important aspect in studies on geoinformation because of the exchange of spatial data. 
The SDI initiative has allocated large sums of money to achieve this goal [3]. Due to the enormous financial resources in public funds, it is necessary to evaluate the actions taken [4]. One of the main objectives of SDIs is to create horizontal and vertical links between entities that create and use spatial data [5]. Open Access to Public Sector Information (PSI) offers the opportunity to develop new products and applications and increase the efficiency and effectiveness of existing ones. Geographical information is very important for the public sector, because geographical information is necessary for sustainable development. It is an important component of many public tasks and areas [6]. Numerical maps have become components of cartography through Geographic Information Systems (GIS) and the place where they are collected and made available. These systems collect data and metadata and, through analysis, gain knowledge of the terrain, which has a precise location in the land plot [7]. "The time and resources used to study existing spatial data or to decide whether they can be used for a specific purpose constitute a decisive obstacle to the optimal use of available data" (Directive 2007/2/EC of the European Parliament and of the Council of 14 March 2007 establishing an Infrastructure for Spatial Information in the European Community (INSPIRE)). As defined in [8] by the SDI, (a) the "National Spatial Data Infrastructure" ("NSDI") means the technology, policies, standards, and human resources necessary to acquire, process, store, distribute, and improve the use of geospatial data; and (b) "spatial data" have geographical coordinates and characteristics and boundaries. The implementation of the INSPIRE Directive (Infrastructure for Spatial Information in the European Community) allows access and sharing of geographical data and enables interoperability between systems [9]. Every data integration action into an integrated European Geographical Information System aims to harmonize economic growth, social integration, and environmental protection, i.e., sustainable development in accordance with EU directives [10]. We can search for sources of information from remote sensing, mapping, and surveying. Statistical data, on the other hand, are threatened by a special agency called the "National Geospatial Data Exchange Centre". This is a network of producers, managers, and users of geoinformation who are connected electronically. In European Union countries, the stages of work on the creation and development of national geoproducts are studied. Researchers [11-13], and Dukaczewski and Bielecka [14] analyzed the compliance of geoportal content with the INSPIRE Directive and organizational, legal, and technical solutions, the scope of spatial data and services, and the functionality, timeliness, and availability of data in different countries. The creators of Geoportals create intuitive tools in the cloud so that users need the Internet and a browser, and systems automatically coordinate and visualize data for the user [15]. It is the geoportal users themselves who expect the mechanisms for searching and navigating the portal to be easier. However, without the use of programming languages, because they are called upon to search engine mechanisms, geoportal solutions are used. Therefore, geoportals are popular and have high user satisfaction [16]. The key is choosing the type of data that can be integrated with other information at the international level [17]. To this end, catalogued information that is standardized to international ISO standards is used, which ensures the integrity of national data and data consistency at the international level [18-24]. Researchers are developing conceptual models to allow geographic data to be implemented in geographic information systems in accordance with the ISO 19.100 family standards [25-32] and also to allow an assessment of the quality of geographic information in accordance with the ISO 19.100 family of national geoporlations to be carried out [2,23,33-37]. According to Leibovici and others [38], it is important to strive to separate the QA process from the DCDF stage, while integrating them within an approach that is analogous to the Bayesian paradigm; this ISO quality criterion cannot be rejected. There are four types of geoportal in maritime and coastal areas: Atlas-like geoportals, Hydrographic Office geoportals, Oceanographic/Marine Data Centre geoportals, and hybrid geoportals [39]. GeoTest created a method to test the functionality of geoportals based on the ISO 9241-1 standard. It established a methodology for assessing effectiveness, efficiency, and satisfaction [40]. For the real estate cadastre, models based on the Land Administration Domain Model (LADM), defined within ISO 19152, were built [41-45]. For the real estate cadastre, models based on the Land Administration Domain Model (LADM), defined within ISO 19.152 [46], were built using the ISO 14.825 Geographic Data Files (GDF) standard for Intelligent 
Transport Systems (ITS) [47-49]. The other method is to evaluate the results of the validation of datasets/services in the INSPIRE Geoportal Metadata Validator and ETF test projects from github to test the compliance of services with the requirements of the INSPIRE technical guidelines [50].

\section{Materials and Methods}

The aim of the study was to compare the degree of advancement in studies on creating and developing geoportals. The subject of the research was the existing Polish National Spatial Data Infrastructure and Italian National Spatial Data Infrastructure. The analysis covered the following systems: Geoportal.gov.pl (Poland) and National Geoportal (Italy). The research methodology is presented in Figure 1. A comparative analysis method was adopted for the study, using a combination of Dukaczewski's [14] and Dawidowicz's [1] methods. The research was based on the use of the functional matrix (data and service scope) and compliance with the legal framework derived from the INSPIRE Directive guidelines. According to the five-point Tilgner scale [51], the following system quality classes were adopted for evaluation:

- $\quad 0-20 \%$ points—very poor quality;

- $21-40 \%$ points-poor quality;

- $\quad 41-60 \%$ of the points-sufficient quality;

- $61-80 \%$ of the points-good quality;

- $\quad 81-100 \%$ points—very good quality.

After a detailed analysis of the EU decrees, it was assumed that the ISO 19.100 series of standards should be adopted as the technical basis for INSPIRE, so we examined whether the obligatory 34 topics were implemented in the Polish and Italian legal acts. A gustatory analysis of the implementation at the national and regional levels was then performed. Additionally, a percentage synthetic quality indicator of Polish and Italian geoportals will be determined, calculated by summing up the percentage range of functionality and verifying compliance with the Ubiquitous Public Access Contextual Information Model (UPA) defined by the International Organization for Standardization (ISO) 19100.

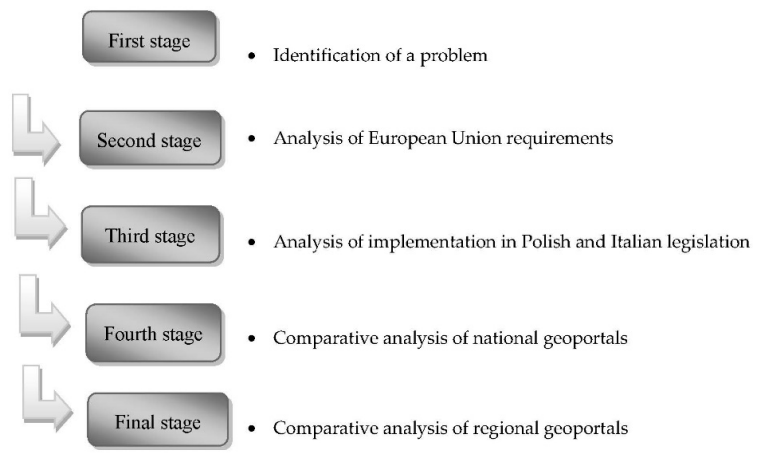

Figure 1. Procedure of conducted research Source: own study.

Each of the countries in the Community, based on the assumptions of the INSPIRE Directive, introduced a Geoportal by amending or creating new reference legislation.

The Poland reference legislation:

- $\quad$ Act of 17 May 1989. Geodetic and cartographic law (Dz.U. 2010 No 193 item 1287);

- $\quad$ Act of 4 March 2010 on Spatial Information Infrastructure (Dz.U. 2010 No 76 item 489);

- Act of 27 August 2009 on public finances (Journal of Laws 2009 No 157 item 1240);

- Act of 17 February 2005 on the Informatization of Activities of Entities Performing Public Tasks (Journal of Laws of 2005 No. 64 item 565, amended);

- Regulation of the Council of Ministers of 11 October 2005 on the minimum requirements for public registers and exchange of information in electronic form (Dz. U. 2005 No. 214 item 1781); 
- Act of 4 February 1994 on Copyright and Related Rights (Journal of Laws of 1994, No. 24, item 83 with amendments);

- Effective and drafted executive regulations to the Spatial Information Infrastructure Act and the Geodetic and Cartographic Law.

- The Italian reference legislation:

- $\quad$ Legislative Decree of 27 January 2010, N. 32 Implementation of the INSPIRE Directive;

- Decree of the President of the Council of Ministers 12 January 2016: Method of functioning of the National Council for Territorial and Environmental Information;

- Legislative Decree of 7 March 2005, N. 82 Digital Administrative Code;

- Legislative Decree of 26 August 2016, N. 179 Amendments and additions to the Digital Administration Code;

- Decree of 10 November 2011-Technical regulations for determining the content of the national spatial data repertoire, as well as the procedure for its initial creation and updating;

- Decree of 10 November 2011-Technical regulations for defining content specifications for geotopographic databases;

- Decree of 10 November 2011-Technical regulations for the creation, documentation, and exchange of digital orthophotography on a nominal scale of 1:10,000.

\section{Results and Discussion}

Directive 2007/2/EC of 2007 established spatial information infrastructure in Europe (INSPIRE) for Community environmental policies and policies or activities that may have an environmental impact. The INSPIRE Directive requires Member States to develop and implement spatial information infrastructure as part of the European Union's spatial information infrastructure. The existing and proposed Community provisions on INSPIRE and other documents resulting from the work on INSPIRE to the countries of the community are intended to facilitate the creation of the INSPIRE geoportal by the European Commission's Community Research Centre (JRC), which is intended to be the central hub of the European Spatial Information Infrastructure. The efficient use of a geoportal is possible only if the data are shared. Shared layers contain information about the approximate boundaries of parcels, but they can only be used for approximate identification of the spatial location of the parcel and its estimate of the plot. From the assumption of the scope and access to a specific data group, each Member State should act in accordance with Commission Regulation (EU) No 268/2010 of 29 March 2010, which implemented Directive 2007/2/EC of the European Parliament and the Council regarding the access of Community institutions and bodies to the spatial datasets and services of the Member States in accordance with harmonised conditions (OU 111). L 83 of 30 March 2010 (p. 8 to 9) and Directive 2007/2/EC of the European Parliament and the Council from 14 March 2007 concern the establishment of spatial information infrastructure in the European Community (INSPIRE) (OJ L 133, 11.12.2007, p. 1). L 108, 25.4.2007, p. 1-14).

The INSPIRE Directive was incorporated into Italian law by the legislative decree established on 27 January 2010 (N. 32), with which a national spatial information and environmental monitoring infrastructure was established in Italy as a Community infrastructure hub. The Ministry of Environment and The Protection of The Territory and the Sea act as the competent authority for the implementation of the Decree for which Article 10(1) of Regulation (EC) No 1782/2003 details the implementation of the Regulation. Article 8 explains that the National Geoportal is a point of access to the purposes of the INSPIRE Directive. On the other hand, in Poland, under the Act of 4 March 2010 on Spatial Information Infrastructure, a project was set up for geoportal 2, which dealt with the implementation and maintenance of INSPIRE services.

As defined in INSPIRE, "infrastructure for spatial information" includes metadata, spatial data sets, and spatial data services; network services and technologies; and data exchange, access and use. Data infrastructure is also a national spatial information resource and includes technologies and 
techniques for data discovery, storage, and cataloguing [7]. In Europe, national and regional initiatives have been taken to legitimize the Spatial Data Infrastructure, mainly by public administrations, which are not often private by public order [52]. Land administration systems are subject to continuous reforms, and EU member countries have different regulations, but the common feature is that the effectiveness of land administration systems depends on the efficiency of data quality, although there is no internationally recognized methodology for assessment and comparison. Therefore, the authors check the quality of data that come from the available layers in geoportals.

\subsection{Italian Geoportal}

The National Spatial Data Directory (RNDT) was created on the basis of Article 59 of the Digital Administration Code, Legislative Decree 82/2005 (CAD) and was identified as a database of national importance on the basis of Article 60. In accordance with article 59 of the CAD mentioned above, the technical specifications defining the content of the RNDT, as well as its implementation and updates, were defined by the Committee for Technical Regulations on Spatial Data of the Polish Academy of Sciences and adopted by the Ministerial Decree of 10 November 2011 (Journal of Laws No. 48 of 27 February 2012-SO No. 37) that was put forward by the Minister of Public Administration and Innovation in agreement with the Minister of Environment and Land and Sea Protection. The RNDT regulations are a national catalog of geographic metadata and PTA services provided by public government authorities and constitute a data register. They are available in the geoportal and are downloadable in order to show their reliability. The RNDT is based on the ISO Standards 19115, 19119 and TS 19.139, as defined by the ISO/TC211 Technical Commission, which deals with geographic information standards. Compliance with the technical provisions of the RNDT ensures simultaneous compliance with Regulation (EC) No. 1782/2003. Legislative Decree No. 1. 32/2010 implements the INSPIRE directive for metadata in Italy and has become a national infrastructure for spatial and environmental information.

Figure 2, developed in the Repertorio Nazionale dei Dati Territoriali, the portal of the National Catalog for Spatial Data (RNDT), shows a map of Italy with the geological distribution and bathymetry of the surrounding seas. The geoportal provides access to 100 thematic layers. Menus can be moved to different places on the screen, and layers can be set in order of display, and they can even be set to permeability and legend display, but only for one layer. The user can choose from five background maps, and these are orthophotos from 1998, 1994, 2000, 2006 and 2012. Additionally, it is possible to enable 3D view, make measurements using the WMS or ArcGIS service, or save or print the map.

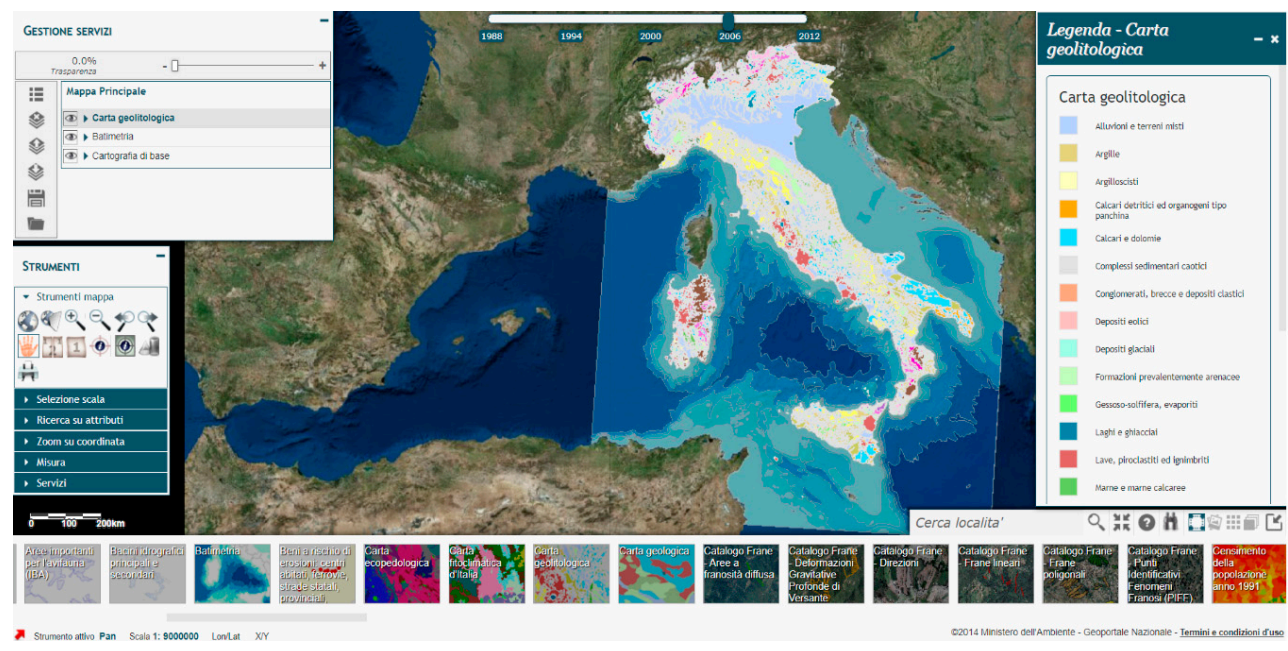

Figure 2. Repertorio Nazionale dei Dati Territoriali, the portal of the National Catalog for Spatial Data (RNDT). Source: own study based on data from http://www.pcn.minambiente.it/viewer/. 


\subsection{Geoportal of Poland}

Within the GEOPORTAL.GOV.PL project, the infrastructure of the National Spatial Information Infrastructure (KIIP) nodes was created. These cooperate with each other and provide services that range from searching and sharing data to analysis. The network of KIIP nodes was based on three levels: central, provincial, and county. As a result of the design work, an Internet portal was also created (www.geoportal.gov.pl). This acts as a broker, providing users with data and geospatial services.

Figure 3, developed in Geoportal 2, shows The portal of the Central Office of Geodesy and Cartography, a map of Poland divided into Land uses. The portal offers a choice of several languages, in Polish and English, but the legends are generated in Polish. The user can use the national version, the INSPIRE version, and the 3D version and can check the catalog of resources and download mobile applications, e.g., for geocoding or browsing on a mobile device. In the INSPIRE version, the user can use 40 thematic layers in the portal, where it is possible to turn the visibility of data on and off and additionally use the WMS and WMTS browsing services. In the national version, the user has 128 thematic layers at their disposal, in which it is possible to turn the visibility of data on and off and additionally use the WMS and WMTS browsing services.

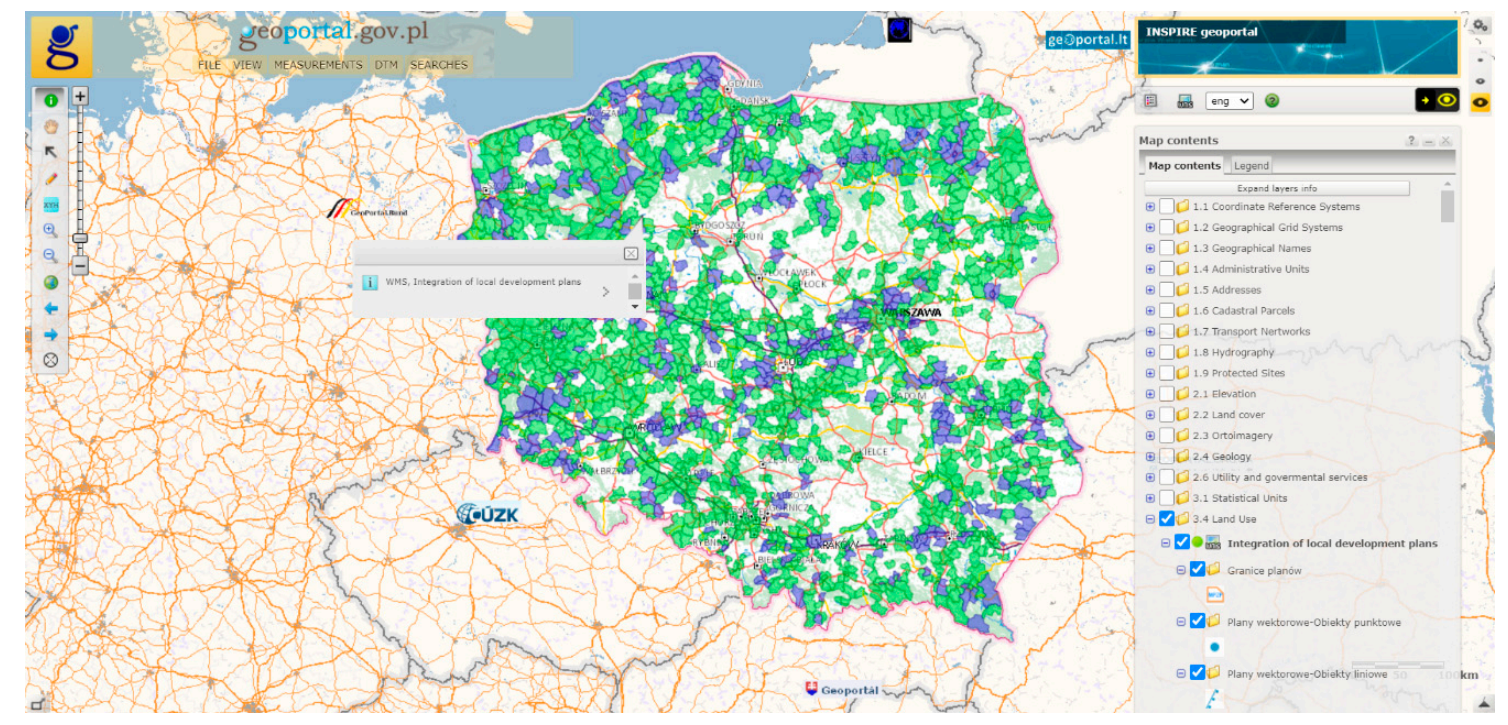

Figure 3. Geoportal 2, the portal of the Central Office of Geodesy and Cartography. Source: own study based on data from. https://mapy.geoportal.gov.pl/imap/Imgp_2.html?gpmap=gp0.

\subsection{Bari Geoportal}

The Territorial Information System (SIT) of the metropolitan area of Bari ("Area Vasta Metropoli Terra di Bari", which includes 41 municipalities) contains a number of online functions that are linked to the access profile. The geoportal provides access to 222 thematic layers. By accessing this anonymously without the need for authentication, the anonymous user can browse data at the regional level concerning PPTR services (DGR 176/2015), PAI and WMS provided by the regional Territorial Information System (SIT Puglia) and the Apulia Basin authorities, including the cartography of the cadastral maps of the selected municipality with all the spatial planning instruments that can be activated through WMS services. The WMS of the Area Vasta Metropoli Terra di Bari related to the general plan (PRG) is also available as an anonymous user. The services available through the SPID can be obtained by logging in with certification. The logged-in user receives a standard set of all city planning tools.

Figure 4 developed in the Territorial Information System (SIT) showing a map of the analyzed part of the city of Bari in terms of public greenery. It was developed using the "Public green" layer with the following attributes: Visual Tree Assessment, Trees-Bushes, Soil, Green Areas, and the base 
map "Aerial with labels" (the user has 5 base maps to choose from the option without a base map). Additionally, the portal generates a legend in Italian. The portal is functional and is an element of a uniform spatial information system for the municipalities of the metropolitan area of Bari. It is possible to add your own thematic layers and data, as well as access to open-source data, geolocation, distance and surface measurements, and street view data and to generate maps in both png and pdf formats. Construction of such a technologically and functionally advanced system was possible using the information available on the geoportal website from the EU Structural Fund for 2007-2013 and the Metropolitan Cities Operational Programme (2014-2020).

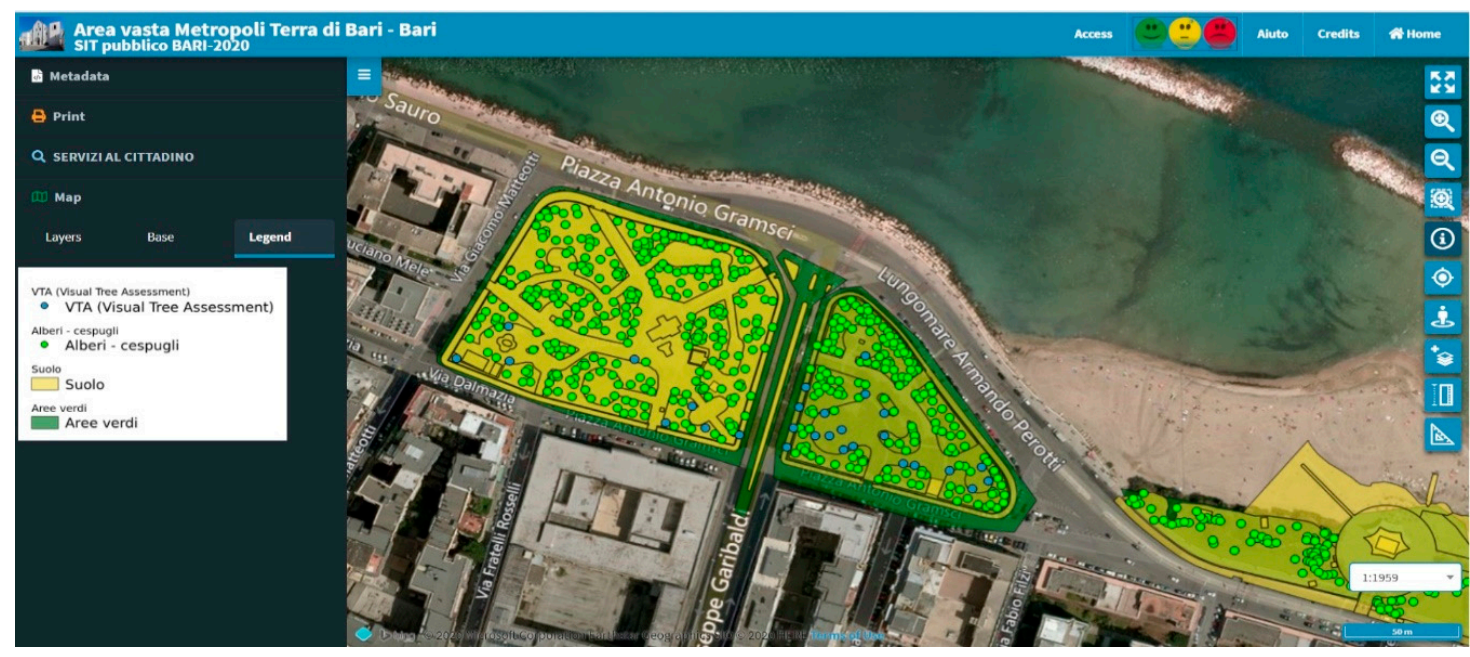

Figure 4. The Territorial Information System (SIT) of the Area Vasta Metropoli Terra di Bari. Source: own study based on data from https://sit.egov.ba.it/en/map/bari/qdjango/106/.

\subsection{Olsztyn Geoportal}

The geoinformation portal of the city of Olsztyn provides universal access to updated reference spatial databases of the city, including, in particular, data from public registers related to the spatial management of the city. This includes spatial development plans, property ownership/ownership structure, as well as decisions/establishments related to the investment and construction process.

Figure 5, developed in the City Spatial Information System of the City of Olsztyn, shows a map of the analyzed part of the city in terms of noise. For Polish towns with more than 100 thousand inhabitants, such maps are obligatory. The purpose of proper categorization of the data access function was to distinguish between two groups of users: (1) internal users, i.e., employees of the office, employees of the City's organizational units covered by the scope of the system's implementation and other authorized entities, organizational units, and natural persons to whom such access has been formally granted, and (2) external users, including all those outside the first group of internal users, i.e., legal persons (institutions and business entities) and natural persons, in particular, residents. The user has 8 thematic layers at his disposal, including city plans in the form of an orthophotomap from 1995, 2005, 2009, and 2017. The MSIPMO application site consists of tool software such as database servers, map servers, and standard GIS software based on licenses of the standard Desktop GIS class and designed for PMSIP specialists and advanced users for tasks related to the handling of the complex geometry of spatial data, performing complex cartographic and analytical works, field inventory, and application software, which consists of internet and intranet map portals.

The implementation of INSPIRE allows for very high data analysis capabilities from anywhere in the world. This success has been recognized by the Cities and especially the European capitals, which have recognized this way of sharing data as functional and attractive to the user. The way data are integrated and the approach to the user and the choice of the system are often different between the portals of cities, regions and the country there is a big difference as in Poland and sometimes, as in 
Italy, they are the same for the whole region. Approaches are different but the goal is the same to make geographical information available in an easy and fast way.

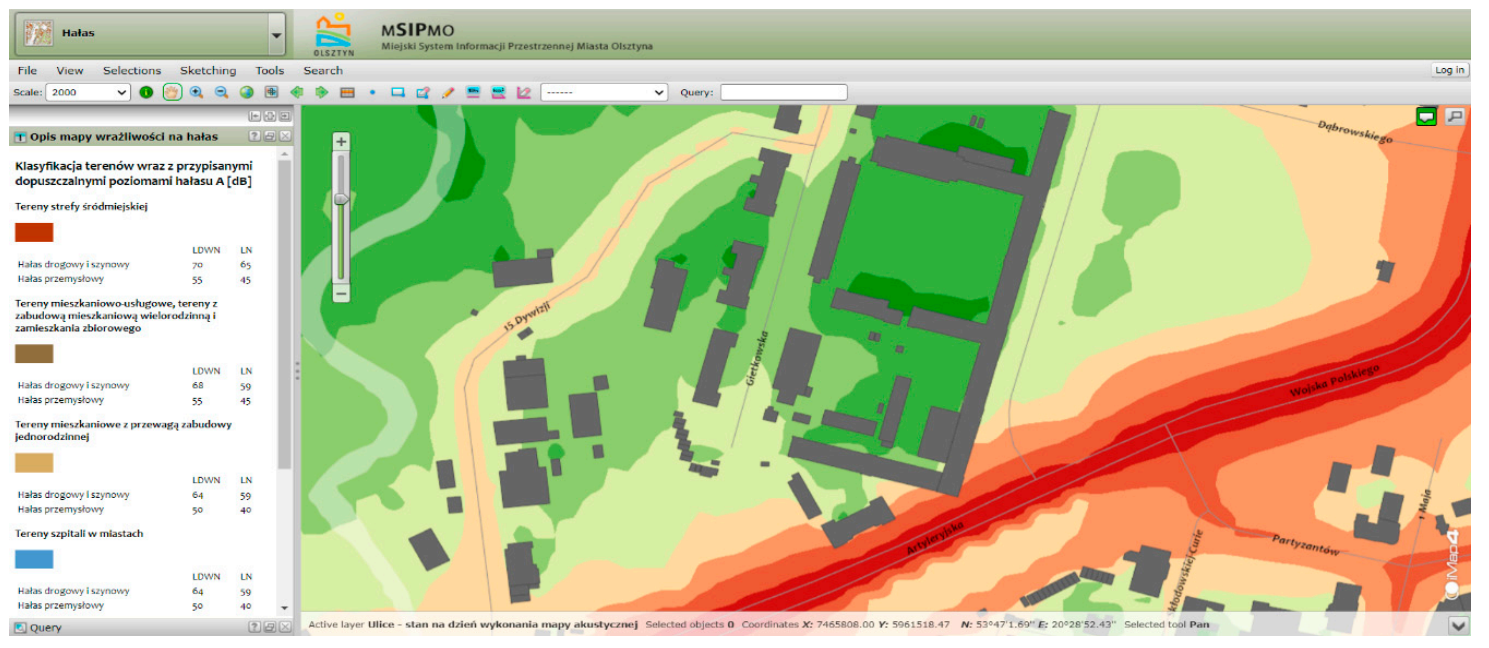

Figure 5. Noise Map of the City of Olsztyn developed in the City Spatial Information System of the City of Olsztyn (MSIPMO). Source: own study based on data from https://msipmo.olsztyn.eu/imap/.

\subsection{Geoportal Verification}

In the research, the percentage functionalities of geoportals (data scope and services-Table 1) and the percentage compliance with the INSPIRE Directive legal framework (Table 2) were determined on the basis of matrixes 1 and 2. Then, on this basis, the quality will be assigned according to the Tilgner scale.

Table 1. Geoportal functionalities (data and service coverage), own study based on data from Raport https://inspire.ec.europa.eu/documents/summary-report-status-implementation-inspire-dire ctive-eu and [1].

\begin{tabular}{llcc}
\hline & \multicolumn{1}{c}{ Functionality } & Polish Geoportal & Italy Geoportal \\
\hline 1 & 2D/3D-three-dimensional view & + & + \\
2 & Generating animation-recording of a flight over the map & - & - \\
3 & Thumbnail/preview & + & + \\
4 & Panel layer-selection of layer display & + & + \\
5 & Legend & + & + \\
6 & Back & + & + \\
7 & Retry & + & + \\
8 & Zoom & + & + \\
9 & Zoom to the selected zone & - & + \\
10 & Zoom to selected objects & + & + \\
11 & Decreasing & + & + \\
12 & Moving the map (the cursor) & + & + \\
13 & Centering & + & + \\
14 & General view-zoom to full extent of the map & - & + \\
15 & Selection of units & + & + \\
16 & Ruler-measure the distance & + & + \\
17 & Measurement of surface & + & + \\
18 & Coordinate system choice & + & + \\
19 & Coordinate transformation & + & + \\
20 & Coordinate measurement & + & + \\
\hline
\end{tabular}


Table 1. Cont.

\begin{tabular}{|c|c|c|c|}
\hline & Functionality & Polish Geoportal & Italy Geoportal \\
\hline 21 & Displaying coordinate exchange rate & + & + \\
\hline 22 & Display coordinates map coverage & + & + \\
\hline 23 & Clear measurements & + & + \\
\hline 24 & Overview map & + & - \\
\hline 25 & Information on specially selected object & + & + \\
\hline 26 & Layer selection & + & + \\
\hline 27 & Scale choice & + & + \\
\hline 28 & Show defined data source & + & + \\
\hline 29 & Layer import & + & + \\
\hline 30 & Moving the selected layer up/down & + & + \\
\hline 31 & Search by history (time) & - & + \\
\hline 32 & Search by name & + & + \\
\hline 33 & Search by map sheet & - & - \\
\hline 34 & Search by key words & + & + \\
\hline 35 & Search by parcel number & + & - \\
\hline 37 & Search by name of the owner & - & - \\
\hline 38 & Search by name, date of birth, date of death & - & - \\
\hline 39 & Search by book of mortgage number & + & - \\
\hline 40 & Search by address & + & - \\
\hline 41 & Search by coordinates points & + & + \\
\hline 42 & Search by type data & - & + \\
\hline 43 & Search by administrative unit & - & - \\
\hline 44 & Search by Parish & - & - \\
\hline 45 & Search by Police Station & - & - \\
\hline 46 & Finding the way & + & - \\
\hline 47 & Find the nearest address & - & - \\
\hline 48 & Transparency & + & + \\
\hline 49 & Show/hide map primer & + & + \\
\hline 50 & Refresh & + & + \\
\hline 51 & Metadata browser & + & + \\
\hline 52 & Metadata enter & - & - \\
\hline 53 & Metadata edit & - & - \\
\hline 54 & Copy to clipboard & + & + \\
\hline 55 & Save the image & + & + \\
\hline 56 & Print settings & + & + \\
\hline 57 & Print & + & + \\
\hline 58 & Data export & - & - \\
\hline 59 & Create link & + & - \\
\hline 60 & Send & - & - \\
\hline 61 & Height & - & - \\
\hline 62 & Orient the north & - & - \\
\hline 63 & Turn & - & - \\
\hline 64 & Tilt & - & - \\
\hline 65 & Camber & - & - \\
\hline 66 & Help & + & + \\
\hline 67 & Reporting errors & + & + \\
\hline 68 & WMS service data adding & + & + \\
\hline 69 & WMTS service data adding & + & - \\
\hline 70 & vector data adding & - & + \\
\hline 71 & vector data downloading & + & - \\
\hline 72 & Timer-maps of different years in the slider & - & + \\
\hline 73 & current orthophotomap & + & - \\
\hline 74 & transcript of the project & - & + \\
\hline
\end{tabular}


Table 2. Comparative analysis of ISO 19.100 implementation source: own study based on data from https://inspire.ec.europa.eu/documents/summary-report-status-implementation-inspire-direct ive-eu and [14].

\begin{tabular}{|c|c|c|c|c|}
\hline Annex. & No & Theme & Polish Geoportal & Italy Geoportal \\
\hline \multirow{9}{*}{ Annex I } & 1 & coordinate reference system & + & + \\
\hline & 2 & IGeographical gridi systemsi & + & + \\
\hline & 3 & IGeographical namesi & + & + \\
\hline & 4 & Administrative units $=$ & + & + \\
\hline & 5 & IAddresses & + & + \\
\hline & 6 & ICadastral parcelsi & + & + \\
\hline & 7 & ITransporti networksi & + & + \\
\hline & 8 & IHydrography (complex) & + & + \\
\hline & 9 & IProtected sitesi (complex) & + & + \\
\hline \multirow{4}{*}{ Annex II } & 1 & IElevation & + & + \\
\hline & 2 & ILand coveri & + & + \\
\hline & 3 & IOrthoimagery & + & + \\
\hline & 4 & Geology & - & + \\
\hline \multirow{21}{*}{ Annex III } & 1 & Statistical units & + & + \\
\hline & 2 & Buildings & + & + \\
\hline & 3 & Soil & + & + \\
\hline & 4 & Land use & - & - \\
\hline & 5 & Human health and safety & - & + \\
\hline & 6 & Utility and governmental services & + & + \\
\hline & 7 & Environmental monitoring facilities & + & + \\
\hline & 8 & Production and industrial facilities & - & - \\
\hline & 9 & Agricultural and aquaculture facilities & + & + \\
\hline & 10 & Population distribution—demography & - & + \\
\hline & 11 & $\begin{array}{l}\text { Area management/restriction/regulation } \\
\text { zones and reporting units }\end{array}$ & - & + \\
\hline & 12 & Natural risk zones & - & + \\
\hline & 13 & Atmospheric conditions & - & - \\
\hline & 14 & Meteorological geographical features & - & - \\
\hline & 15 & Oceanographic geographical features & - & - \\
\hline & 16 & Sea regions & - & - \\
\hline & 17 & Bio-geographical regions & - & - \\
\hline & 18 & Habitats and biotopes & - & - \\
\hline & 19 & Species distribution & - & - \\
\hline & 20 & Energy resources & - & - \\
\hline & 21 & Mineral resources & - & - \\
\hline
\end{tabular}

The percentage functionality of Geoportals is determined on the basis of Table 1 . The advantages mean that the functionality exists and the disadvantages that it does not. After summing up the pluses from Table 1 we conclude that the Polish Geoportal has $66 \%$ functionality and the Italian Geoportal has $61 \%$. According to the Tilgner scale, both Geoportals in terms of functionality were qualified as good quality as a result of the research. On the basis of the conducted research, we conclude that most of the functionalities and cooperation related to the exchange of data and the resource are at a similar level, although acquiring WMTS services, vector data, creating links, detailed search on roads, railroads and other attributes or the current orthophotomap are important elements that are present in the Polish geoportal, although there is no time slider, menu for displaying layers and laying them which resembles GIS software, map tools or data selection depending on the type of data.

The ISO 19.100 series of standards is the technical basis for INSPIRE, and they were established by the European Standardisation Organisation Comité Européen Normalisation-CEN TC/211. The implementation of the elements contained in Table 1 is divided into groups, which are incorporated into the INSPIRE directive as annexes. Member States indicated that by 2010, those made available should have included Annexes I and II, and Annex III should have been available by 2013 [53]. 
The percentage functionality of Geoportals is determined on the basis of Table 2. The advantages mean that functionality exists and the disadvantages that it does not. After summing up the pluses from Table 2 we conclude that the Polish and Italian Geoportal has 70.5 percent. According to the Tilgner scale (Babbie, 2008), both Geoportals in terms of functionality as a result of the research were qualified as good quality. After analyzing the ISO 19.100 standards, we conclude that the Italian geoportal has made more layers available. The Geology layer is present in both portals. This is due to the fact that for several years, the Italian Geological Survey within ISPRA (Italian Institute for Environmental Protection and Research) has had available, in cooperation with Esri Italy, a geographical portal for the dissemination of geological spatial data. The development of the SDI started in 1990 and now consists of more than 15 databases on geological maps and other Italian geotechnical data [54]. Sharing and selecting geological data on maps in geoportals generates problems with semantic dependencies, and different geological database (DB) structures cause interfaces not to function at their full compatibility, so that they can work with other products or systems that exist or will exist in the future, without restricting access or implementation possibilities. The lack of integration is due to the imperfection of programming languages and geological map metadata in the mandatory data stored in the INSPIRE directive, which defines two important guidelines ("Geological Data Specification" and "Metadata Implementation Rules") that can be used for encoding and sharing standard geological information [55]. However, the Land Use layer only covers burnt areas. The natural risk profile was developed on 3 layers in the Italian geoportal, while in Poland it is included as data from Corina Land Cover 2018 because it is more in other thematic portals. In the Italian geoportal, there are two demographic layers, and in the Polish one, there is only one, because there is a separate Geostatistics portal with statistical data in Poland, where it is possible to develop maps showing demography and agricultural and industrial production data. All statistical data collected by the Central Statistical Office in Poland are in a 3-stage division. It is necessary to pay attention to several layers with threats in the Italian geoportal, which are not present in the Poland geoportal. The prototype (ArcGIS for INSPIRE) of the Geoportal, which integrates the geodetic database with the INSPIRE directive scheme, has been used to carry out the entire process of mapping and information transformation of spatial data about soil quality and waste area management into compatible INSPIRE Map (View) services [56]. There is a separate Portal for flood-related hazards in the Poland geoportal. However, the disadvantage of the Italian geoportal is the lack of current data, and in Poland, you have to use a transfer to other thematic portals, e.g., to access noise maps, as shown in Figure 5. Land administration systems are subject to continuous reforms and EU member countries have different regulations, but the common feature is that the effectiveness of land administration systems depends on the efficiency of data, although there is no internationally recognized methodology for assessment and comparison. Therefore, the authors check the quality of data that comes from the available layers of geoportals. In Poland, for example, there is a National Agricultural Support Centre (NASC) for the management of agricultural land. This is what distinguishes the Polish system from others, as this Agency was established to supervise and implement the policy of administering State Treasury agricultural land left over from former State Farms. NASC has an internal spatial information system for analyses of agricultural development and village renewal and revitalization $[57,58]$. The Centre's employees use data from national geoportals as well as dedicated national map geoportals such as the LPIS (Land Parcel Identification System, managed by the Agency for Restructuring and Modernisation of Agriculture-ARMA), the Geostatistics Portal of the Central Statistical Office (https://geo.stat.gov.pl/), maps of average transaction prices of land developed by the Chief Land Surveyor and foreign Sentinel, which are a series of European space missions of remote sensing nature, the website of the German company GEOFABRIK (download.geofabrik.de/), and the EEA website (eea.europa.eu), which contains a huge amount of spatial data for Member States. In Italy, on the other hand, there are different types of natural hazards present, the increased occurrence of which undoubtedly makes the shape of the crisis management system dependent and different from other countries. The system collects, processes, and analyzes data in order to provide information in geoportals (thematic layers) about 
seismic phenomena, volcanic activity, and flooding. In addition, the Italian system is distinguished by the detailed scenarios of actions. Both the Italian system of crisis management and the Polish system of agricultural land management are unique in Europe and can be considered examples of good land administration system practices.

On the basis of percentage analysis of functionality and technical aspects (Tables 1 and 2), a percentage synthetic index of quality of geoportals of Poland and Italy was developed. It is presented in Figure 6. the percentage state of functionality and verification of compliance with the ubiquitous contextual information model of public access (UPA) defined by the International Organization for Standardization (ISO) 19100. It is at a similar level of 67.5\% in Poland and 63\% in Italy. Both geoportals according to the Tilgner scale are of good quality. Each European Union country has a national geoportal. They are very important in the spatial information systems of European cities. As shown in the example of Olsztyn and Bari Geoportals, national geoportals are a source of data and metadata and enable analysis, processing and storage of data. However, City Geoportals have greater functionality because they are used for more tasks. Their interfaces are more user-friendly and have more thematic layers because they are created for a smaller area. Data acquisition is also an important element. Downloading in Geoportals of Cities is very convenient because it allows to download maps and import them to GIS software and assuming georefence of data processing and application of different methods of cartographic presentation [59].

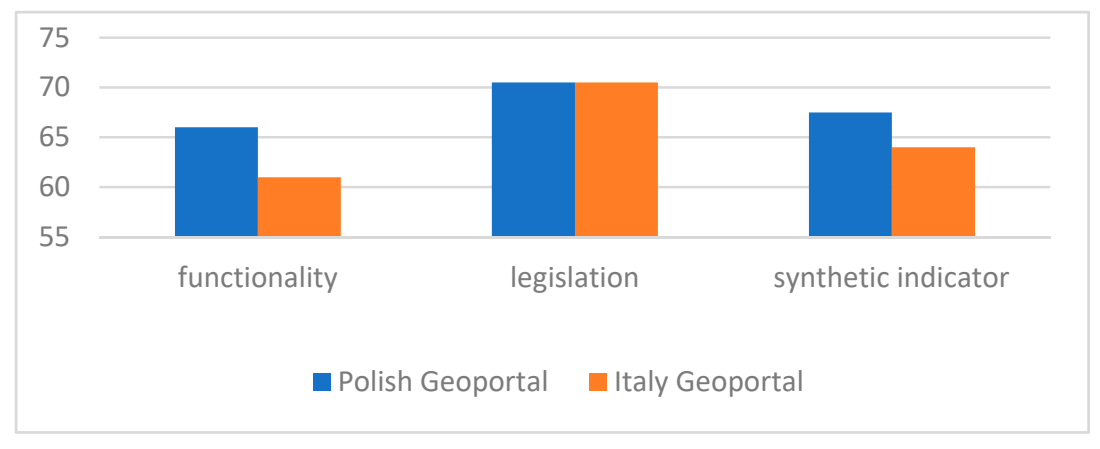

Figure 6. Results of the geoportal research.

\section{Conclusions}

The aim of the study was to develop a methodology for comparing the degree of advancement of work on the creation and development of national geoportals. The developed methodology was verified on the example of Italy and Poland. The analysis covered Polish Geoportal 2 and Italian Il Nuovo Visualizzatore-Geoportale Nazionale. The scope of analysis covered organizational, legal and technical solutions, the scope of spatial data and services covered by the system, functionality of individual geoportals, timeliness and availability of data and their compliance with the INSPIRE Directive. As a result of the analyses, it was concluded that the Georpotals are of good quality and further work on their interoperability needs to be done in order to achieve very good status. The matrices developed can be a universal tool for both the comparison of geoportals and their evaluation, as they indicate shortcomings in functionality and compliance with the INSPIRE Directive. Fragmentation, a lack of harmonization, and duplication of data sets, information and sources are the main premises that have led to the establishment of spatial data infrastructure at the European level. To this end, legal empowerment was introduced in both analyzed States, and national geoportals were developed. However, most major cities develop their spatial information systems and provide data and information on maps. The creation of geoportals requires:

- The creation of laws and executive acts, standards, and guidelines;

- The creation of tools for online publication of spatial data services; 
- The creation of infrastructure, ensuring functioning between data and service providers, preparation of data and services, monitoring of operations, and development of the Geoportal.

A similar research methodology was used by other authors [1,2,11-14] who studied geoportals from most European countries. Geoportals are supplemented with new layers, modernized and adapted to the rules, so it is important to analyze them according to a procedure that takes into account the amount of information and functionality to make the results reliable and comparable. Although geoportals should have the same content by design, they do have different thematic maps. This is mainly because the content that is added is mandatory. Not only the type of data but also the quality and timeliness of the data can differ. Unfortunately, there are no relevant regulations governing the timeliness of data. Geoportals often lack data, necessitating redirection to other specialized portals, but this is not easy to find in the site architecture and the interfaces are different. According to Steudler and others [60], there is no internationally recognized methodology for assessing and comparing the effectiveness of land administration systems. However, the authors assume that the quantity and quality of data determine their usefulness. The ISO standard is the basis for the development, implementation, and certification of the Data Quality Management System. The ISO standard contains requirements concerning the system, which are applicable when an organization needs to demonstrate its ability to continuously deliver a product that meets customer requirements.

In Poland, most regions in municipalities and cities have their own portals, and it is difficult to talk about their integration. On the other hand, in Italy, regions in municipalities and cities have integrated portals. In Italy, portals are regional; therefore, the movement of a portal is facilitated, the developed thematic layers for the areas mostly overlap, and through data normalization, integration in GIS software is provided. In Poland, the choice of engines is free, so the data in the portals are different, there are different interfaces, and it is difficult to achieve data integrity.

Author Contributions: Conceptualization, Marek Ogryzek; Data curation, Marek Ogryzek and Krzysztof Rząsa; Formal analysis, Marek Ogryzek and Eufemia Tarantino; Funding acquisition, Marek Ogryzek and Krzysztof Rząsa; Investigation, Marek Ogryzek; Methodology, Marek Ogryzek; Project administration, Marek Ogryzek; Resources, Marek Ogryzek; Software, Marek Ogryzek; Supervision, Marek Ogryzek; Validation, Marek Ogryzek; Visualization, Marek Ogryzek; Writing—original draft, Marek Ogryzek; Writing—review \& editing, Eufemia Tarantino. All authors have read and agreed to the published version of the manuscript.

Funding: This research received no external funding.

Acknowledgments: The research is supported by grant no. 05/WFKIW/2020 from the Polish National Agricultural Support Center OT Olsztyn.

Conflicts of Interest: The authors declare no conflict of interest.

\section{References}

1. Dawidowicz, A.; Źróbek, R. Hierarchical development of the Spatial Data Infrastructures as a globalization trend. In Proceedings of the 2016 Baltic Geodetic Congress (BGC Geomatics), Gdansk, Poland, 2-4 June 2016; pp. 147-153.

2. Dawidowicz, A.; Sońta, M. Analiza porównawcza wybranych geoportali europejskich. Acta Sci. Polonorum. Adm. Locorum 2014, 13, 59-76.

3. Crompvoets, J. National Spatial Data Clearinghouses Worldwide Development and Impact. Ph.D. Thesis, Wageningen University, Wageningen, The Netherlands, 2006.

4. Crompvoets, J.; Leuven, K.U.; Rajabifard, A.; Van Loenen, B.; Delgado, T. A Multi-View Framework to Assess Spatial Data Infrastructures Building Information Modelling for Land Administration View Project Big Data, Recommender Systems and Social Applications View Project. 2008. Available online: https://www.researchga te.net/publication/37791532_A_Multi-View_Framework_to_Assess_Spatial_Data_Infrastructures (accessed on 9 March 2020).

5. Mijić, S.N.; Šestić, M. Future development of NSDI based on the European INSPIRE Directive-A case study of a Bosnian and Herzegovinian geoportal. Int. J. Spat. Data Infrastruct. Res. 2018. [CrossRef] 
6. van Loenen, B.; Grothe, M. INSPIRE Empowers Re-Use of Public Sector Information. Int. J. Spat. Data Infrastruct. Res. 2014, 9, 96-106. Available online: https://ijsdir.sadl.kuleuven.be/index.php/ijsdir/article/vie w/353/362 (accessed on 9 March 2020).

7. Maguire, D.; Longley, P. The emergence of geoportals and their role in spatial data infrastructures. Comput. Environ. Urban Syst. 2005, 29, 3-14. [CrossRef]

8. Register, F. Presidential Documents Title 3-The President Coordinating Geographic Data Acquisition and Access: The National Spatial Data Infrastructure. 1993. Available online: https://www.archives.gov/files/fed eral-register/executive-orders/pdf/12906.pdf (accessed on 9 March 2020).

9. Gunay, A.; Akcay, O.; Altan, M.O. Building a semantic based public transportation geoportal compliant with the INSPIRE transport network data theme. Earth Sci. Inform. 2013, 7, 25-37. [CrossRef]

10. Ogryzek, M.; Klimach, A.; Niekurzak, D.; Pietkiewicz, M. Using Cartographic Documents to Provide Geoinformation on the Rights to Real Estate-Taking Poland as an Example. ISPRS Int. J. Geo-Inf. 2019, 8, 530. [CrossRef]

11. Adamczyk, T.; Begović, V.; Bieda, A.; Bielecka, E.; Bugaj, P.; Dawidowicz, A.; Džunić, I.; Gajos, M.; Jankowska, M.; Kereković, D.; et al. Spatial Data in Wide Geospace; Nacionalna knjižnica: Zagreb, Croatia, 2014; p. 121.

12. Dawidowicz, A.; VoB, W.; Leonard, B. Land Administration Systems Development Trends-A Case Study. Real Estate Manag. Valuat. 2013, 21, 83-92. [CrossRef]

13. Dukaczewski, D.; Ciołkosz-Styk, A.; Sochacki, M. Regional geoportals in selected European countries-A comparative study. Rocz. Geomatyki 2012, 4, 77-93.

14. Dukaczewski, D.; Bielecka, E. Analiza Porównawcza Krajowych Geoportali W Europie. Rocz. Geomatyki Ann. Geomat. 2009, 7, 35-60.

15. Rautenbach, V.; Coetzee, S.; Iwaniak, A. Orchestrating OGC web services to produce thematic maps in a spatial information infrastructure. Comput. Environ. Urban Syst. 2013, 37, 107-120. [CrossRef]

16. Bogdanovic, M.; Stanimirović, A.; Stoimenov, L. Methodology for geospatial data source discovery in ontology-driven Geo-Inf. integration architectures. J. Web Semant. 2015, 32, 1-15. [CrossRef]

17. Zygmunt, M.; Gargula, T.; Klapa, P. Reduction of Circular Arcs in European Cadastral Systems-The Proposal of a Solution Referring to the Recommendations of the INSPIRE Data Specification on Cadastral Parcels. ISPRS Int. J. Geo-Inf. 2020, 9, 27. [CrossRef]

18. Sladić, D.; Radulović, A.; Govedarica, M.; Jovanović, D.P. Geographical Information Systems Theory, Applications and Management: Third. Google Książki. Available online: https://books.google.pl/books?id=7dmBDwAAQBAJ\&pg=PA129\&lpg=PA129\&dq=Sladić, +D.;+R adulović, +A.;+Govedarica, +M.;+Jovanović, +D.;+Pržulj, +D.+The+Use+of+Ontologies+in+Cadastral+Sy stems.+Comput.+Sci.+Inf.+Syst.+2015,+12,+1033--1053.\&source=bl\&ots=_ZXck6ZnXk\&sig= $($ accessed on 9 March 2020).

19. Kang, T. Development of a Conceptual Mapping Standard to Link Building and Geospatial Information. ISPRS Int. J. Geo-Inf. 2018, 7, 162. [CrossRef]

20. Bakillah, M.; Liang, S.H.L.; Zipf, A.; Arsanjani, J.J. Semantic Interoperability of Sensor Data with Volunteered Geographic Information: A Unified Model. ISPRS Int. J. Geo-Inf. 2013, 2, 766-796. [CrossRef]

21. Janečka, K.; Souček, P. A Country Profile of the Czech Republic Based on an LADM for the Development of a 3D Cadastre. ISPRS Int. J. Geo-Inf. 2017, 6, 143. [CrossRef]

22. Jiménez, M.; González, M.; Amaro, A.; Fernández-Renau, A. Field Spectroscopy Metadata System Based on ISO and OGC Standards. ISPRS Int. J. Geo-Inf. 2014, 3, 1003-1022. [CrossRef]

23. Brodeur, J.; Coetzee, S.; Danko, D.; Garcia, S.; Hjelmager, J. Geographic Information Metadata-An Outlook from the International Standardization Perspective. ISPRS Int. J. Geo-Inf. 2019, 8, 280. [CrossRef]

24. Athanasiou, K.; Sutherland, M.; Kastrisios, C.; Tsoulos, L.; Griffith-Charles, C.; Davis, D.; Dimopoulou, E. Toward the Development of a Marine Administration System Based on International Standards. ISPRS Int. J. Geo-Inf. 2017, 6, 194. [CrossRef]

25. Migliorini, S.; Grossi, P.; Belussi, A. An Interoperable Spatio-Temporal Model for Archaeological Data Based on ISO Standard 19100. J. Comput. Cult. Herit. 2017, 11, 1-28. [CrossRef]

26. Ristić, A. Modeling cadastral records as a part of national spatial data infrastructure. Int. Multidiscip. Sci. GeoConference SGEM 2011, 2, 629. 
27. Bartha, G. Inspire Metadata Editors. An. Stiintifice Ale Univ. Alexandru Ioan Cuza Din Iasi-Ser. Geogr. 2012, 58, 249-260.

28. Denis, M.; Jaroszewicz, J.; Parzyński, Z. Standardization of the spatial data concerning spatial management planning in Poland. In Proceedings of the 14th SGEM GeoConference on Informatics, Geoinformatics and Remote Sensing, Albena, Bulgaria, 17-26 June 2014.

29. Michalak, J. Groundwater flow models construction with application of data from geoinformation infrastructure inspire [Budowa modeli przepływu z wykorzystaniem danych infrastruktury geoinformacyjnej inspire]. Biul. Panstw. Inst. Geol. 2008, 431, 61-168.

30. Karpinskyi, Y.; Lazorenko-Hevel, N. Topographic mapping in the National Spatial Data Infrastructure in Ukraine. In E3S Web of Conferences; EDP Sciences: Ullis, France, 2020; Volume 171, p. 02004.

31. Mościcka, A.; Zwirowicz-Rutkowska, A. On the Use of Geographic Information in Humanities Research Infrastructure: A Case Study on Cultural Heritage. ISPRS Int. J. Geo-Inf. 2018, 7, 106. [CrossRef]

32. Hong, S. Air Quality Context Information Model for Ubiquitous Public Access to Geographic Information. ISPRS Int. J. Geo-Inf. 2018, 7, 316. [CrossRef]

33. Evaluation of the Data Quality of Digital Elevation Models in the Context of Inspire/Hodnotenie Kvality Digitálnych Výškových Modelov V Kontexte Inspire. Geosci. Eng. 2013, 59, 9-24. [CrossRef]

34. Pachelski, W.; Zwirowicz-Rutkowska, A.; Michalik, A. Modelling air quality according to INSPIRE data specifications, ISO standards and national regulations. J. Water Land Dev. 2017, 35, 167-172. [CrossRef]

35. López, E.; Gutiérrez, J.; Gómez, G. Measuring Regional Cohesion Effects of Large-scale Transport Infrastructure Investments: An Accessibility Approach. Eur. Plan. Stud. 2008, 16, 277-301. [CrossRef]

36. Gutiérrez, R.; Farjas, M.; Velázquez, I. EPIARQ: A Spatial Data Infrastructure for research in medieval epigraphy. Hortus Artium Mediev. 2015, 21, 324-334. [CrossRef]

37. Parzyński, Z. Podstawy modelowania georeferencyjnych baz danych. Arch. Fotogram. Kartogr. i Teledetekcji 2010, 21, 315-326.

38. Leibovici, D.G.; Rosser, J.F.; Hodges, C.; Evans, B.; Jackson, M.J.; Higgins, C.I. On Data Quality Assurance and Conflation Entanglement in Crowdsourcing for Environmental Studies. ISPRS Int. J. Geo-Inf. 2017, 6, 78. [CrossRef]

39. Georis-Creuseveau, J.; Longhorn, R.; Crompvoets, J. Survey of National Coastal and Marine geoportals: European developments. In Proceedings of the Inspire Conference-Geospatial World Forum, Lisbon, Portugal, 25-29 May 2015.

40. He, X.; Persson, H.; Östman, A. Geoportal Usability Evaluation. Int. J. Spat. Data Infrastruct. Res. 2012. [CrossRef]

41. Radulović, A.; Sladić, D.; Govedarica, M. Towards 3D Cadastre in Serbia: Development of Serbian Cadastral Domain Model. ISPRS Int. J. Geo-Inf. 2017, 6, 312. [CrossRef]

42. Dawidowicz, A.; Kulawiak, M.; Zysk, E.; Kocur-Bera, K. System architecture of an INSPIRE-compliant green cadastre system for the EU Member State of Poland. Remote. Sens. Appl. Soc. Environ. 2020, 20, 100362. [CrossRef]

43. Van Oosterom, P.; Lemmen, C. The Land Administration Domain Model (LADM): Motivation, standardisation, application and further development. Land Use Policy 2015, 49, 527-534. [CrossRef]

44. Bydłosz, J. The application of the Land Administration Domain Model in building a country profile for the Polish cadastre. Land Use Policy 2015, 49, 598-605. [CrossRef]

45. Kalogianni, E.; Van Oosterom, P.; Dimopoulou, E.; Lemmen, C. 3D Land Administration: A Review and a Future Vision in the Context of the Spatial Development Lifecycle. ISPRS Int. J. Geo-Inf. 2020, 9, 107. [CrossRef]

46. Jetlund, K.; Onstein, E.; Huang, L. IFC Schemas in ISO/TC 211 Compliant UML for Improved Interoperability between BIM and GIS. ISPRS Int. J. Geo-Inf. 2020, 9, 278. [CrossRef]

47. Jetlund, K.; Onstein, E.; Huang, L. Adapted Rules for UML Modelling of Geospatial Information for Model-Driven Implementation as OWL Ontologies. ISPRS Int. J. Geo-Inf. 2019, 8, 365. [CrossRef]

48. Jetlund, K.; Onstein, E.; Huang, L. Information Exchange between GIS and Geospatial ITS Databases Based on a Generic Model. ISPRS Int. J. Geo-Inf. 2019, 8, 141. [CrossRef]

49. Wolny, A.; Ogryzek, M.; Źróbek, R. Towards Sustainable Development and Preventing ExclusionsDetermining Road Accessibility at the Sub-Regional and Local Level in Rural Areas of Poland. Sustainability 2019, 11, 4880. [CrossRef] 
50. Holms, J. An overview of data from datasets registered in latvian spatial metadata catalogue. Int. Multidiscip. Sci. GeoConference SGEM 2017, 17, 783-790. [CrossRef]

51. Babbie, E. Podstawy Badań Społecznych, Przeł. W. Betkiewicz. Warszawa Wydaw. Nauk. PWN 2008. p. 578. Available online: http://csr-d.pl/wp-content/uploads/2015/02/Earl-Babbie-Badania-Spo\%C5\%82eczne-w-Pra ktyce.pdf (accessed on 9 March 2020).

52. Bregt, A.K. Building European spatial data infrastructures, by Ian Masser. Int. J. Geogr. Inf. Sci. 2011, 25, 1905-1906. [CrossRef]

53. Bartha, G.; Kocsis, S. Standardization of geographic data: The european inspire directive. Eur. J. Geogr. 2011, 2, 79-89.

54. Cipolloni, C.; Campanile, G.; Italia, E. The semantic search engine on the Geological portal of Italy. In Proceedings of the INSPIRE Conference 2013, Florence, Italy, 23-27 June 2013.

55. Balestro, G.; Piana, F.; Fioraso, G.; Perrone, G.; Tallone, S. Sharing data and interpretations of geological maps via standardised metadata and geoportals. Ital. J. Geosci. 2013, 132, 254-262. [CrossRef]

56. Chliaoutakis, A.; Kydonakis, A.; Doula, M.K.; Kavvadias, V.A.; Sarris, A.; Papadopoulos, N. Geospatial Tools for Olive Oil Mills' Wastes (OOMW) Disposal Areas Management. In Proceedings of the 32nd Annual EARSeL Symposium 2012, Mykonos, Greece, 21-24 May 2012.

57. Ogryzek, M.; Ciski, M. Cartographic Methods of Presentation the Average Transaction Prices of the Undeveloped Land. Civ. Environ. Eng. Rep. 2018, 28, 85-100. [CrossRef]

58. Ciski, M.; Rzasa, K.; Ogryzek, M. Analysis of Existing Spatial Information Systems in Terms of its Use for the Renewal and Revitalization of Rural Areas. Balt. Surv. 2018, 8, 13-22. [CrossRef]

59. Ogryzek, M.P.; Rzasa, K.; Ciski, M. The role of the National Support Centre for Agriculture in the process of revitalization and renewal of the rural areas. J. Water Land Dev. 2019, 42, 143-149. [CrossRef]

60. Steudler, D.; Rajabifard, A.; Williamson, I.P. Evaluation of land administration systems. Land Use Policy 2004, 21, 371-380. [CrossRef]

Publisher's Note: MDPI stays neutral with regard to jurisdictional claims in published maps and institutional affiliations.

(C) 2020 by the authors. Licensee MDPI, Basel, Switzerland. This article is an open access article distributed under the terms and conditions of the Creative Commons Attribution (CC BY) license (http://creativecommons.org/licenses/by/4.0/). 